\title{
Penggunaan Kinetin, Asam Naftalen Asetat, dan Benzil Adenin dalam Induksi Kalus Kecubung (Datura metel L.) Secara In Vitro
}

\section{Use of Kinetin, Naphthalene Acetate Acid, and Benzyl Adenine in Induction of Amber Callus (Datura metel L.) In Vitro}

\author{
Yulita Nurchayati ${ }^{1}$, Santosa $^{2}$, Laurentius H. Nugroho ${ }^{2}$ dan Ari Indrianto ${ }^{2}$ \\ ${ }^{1)}$ Departemen Biologi, Fakultas Sains dan Matematika Universitas Diponegoro, Semarang \\ ${ }^{2)}$ Fakultas Biologi, Universitas Gadjah Mada, Yogyakarta \\ *Email : yulita.yoko@gmail.com
}

Diterima 8 Januari 2018 / Disetujui 31 Januari 2018

\begin{abstract}
ABSTRAK
Kecubung (Datura metel L.) merupakan tumbuhan penghasil hyosciamin dan skopolamin, yang berkasiat sebagai anticholergic dan spasmolytic. Kedua metabolit dapat ditingkatkan produksinya dari kultur kalus. Induksi kalus dari daun kecubung dilakukan dengan menggunakan aplikasi zat pengatur tumbuh (ZPT). Tujuan dari penelitian ini adalah untuk mempelajari respon dan perkembangan daun kecubung terhadap beberapa macam hormon dan untuk menseleksi kalus yang terbentuk secara in vitro. Penelitian ini menggunakan Rancangan Acak Lengkap dengan 6 perlakuan ZPT dalam medium Murashige \& Skoog (MS) yaitu tanpa hormon, Kinetin tunggal, NAA tunggal, kombinasi Kinetin dan NAA, BA tunggal serta kombinasi BA dan NAA. Daun yang telah disterilkan ditumbuhkan dalam medium MS dengan penambahan sukrosa $3 \%$ dan beberapa ZPT perlakuan dan diberikan 5 ulangan. Kalus yang terbentuk disubkultur dalam medium yang sama formulasinya untuk mengoptimalkan pertumbuhan. Hasil menunjukkan bahwa kalus dapat terbentuk pada semua medium yang diujikan. Kalus yang remah diperoleh dari medium MS dengan ZPT kombinasi kinetin $3 \times 10^{-5} \mathrm{M}$ dan NAA $10^{-5} \mathrm{M}$. Respon kalus yang berbeda diperoleh dari medium dengan penambahan BA tanpa NAA. Penambahan BA tunggal $6 \times 10^{-6} \mathrm{M}$ dalam medium MS menginduksi kalus yang embrionik.
\end{abstract}

Kata kunci : induksi kalus, zat pengatur tumbuh, kalus remah, kalus embrionik

\section{ABSTRACT}

Datura metel L. is plant produced hyosciamine and scopolamine, which has anticholergic and spasmolytic activities. Both metabolites can be arised by callus culture. Callus induction from the leaves can be established by plant growth regulators (PGR) application. The aims of this experiments are to study leaves respon and the development in several PGR and to screen the callus properly in further stages. This research was conducted by Completely Randomized Design with 6 treatment PGR into Murashige \& Skoog (MS) medium i.e. without hormone, single Kinetin, single Naphtalene acetic acid (NAA), Kinetin combined with NAA, single Benzyl Adenin (BA), and BA combined with NAA. The sterile leaves were initiated in MS medium supplemented 3\% sucrose and several combines of PGR with 5 replicates. Moreover, callus formatted were subcultured three times at the same medium to optimize growth. The result showed that callus could be formatted at all of medium composition. The friable callus was gained at MS by adding with Kinetin $3 \times 10^{-5} \mathrm{M}$ combined with NAA $10^{-5} \mathrm{M}$. Difference respon of leaves was obtained in MS supplemented BA without NAA. This respons indicated that BA $6 \times 10^{-6} \mathrm{M}$ was suitable growth regulator for embrionic callus formation.

Keywords : callus induction, plant growth regulators, friable callus, embrionic callus

\section{PENDAHULUAN}

Tumbuhan menjadi bahan baku yang penting untuk obat herbal karena kandungan senyawa kimianya (Dechaux and Boitel-Conti,
2005). Salah satu tumbuhan dari famili Solanaceae yakni kecubung (Datura metel L.) mengandung senyawa alkaloid kelompok tropan, yakni hyosciamin dan skopolamin, yang berkasiat sebagai anticholergic dan spasmolytic (Alexander 
et al., 2007; Facchini, 2001) dan memiliki aktivitas antibakteri (Bruce, 1999). Eksplorasi kedua senyawa ini dari tumbuhan asalnya memerlukan waktu yang lama, karena dormansi biji dan persentase perkecambahan yang rendah. Biji kecubung tergolong biji yang berkulit keras, sehingga sulit dikecambahkan secara in vitro (Ajungla et al., 2009). Semua bagian dari tumbuhan tersebut dapat menghasilkan alkaloid ketika diinduksi menjadi kalus. Kalus merupakan jaringan yang belum terdiferensiasi, yang diperoleh dengan kultur jaringan. Kalus memiliki kemampuan unuk mensintesis suatu metabolit sekunder. Melalui metode ini, suatu potongan daun dapat mengalami dediferensiasi membentuk kalus. Kalus akan tumbuh di dalam medium buatan yang mengandung nutrisi dan menjalankan metabolisme umumnya bahkan metabolisme sekunder (Mantell \& Smith, 1986; Chawla, 2002; Dewick, 2000). Beberapa metabolit diproduksi dari kalus tumbuhan anatara lain produksi suatu antioksidan dari Morinda citrifolia (Kusdianti, 2007), karotenoid dan klorofil dari jenis Acalypha indica L. (Rahayu, 2002) nikotin dari Nicotiana tabacum L. dan asam askorbat dari Hibiscus sabdariffa (Nurchayati \& Rahmah, 2010).

Induksi kalus menjadi bagian awal yang harus dilakukan untuk mendapatkan kultur kalus secara in vitro maupun untuk pengujian tahap perkembangan selanjutnya. Zat pengatur tumbuh (ZPT) menjadi salah satu unsur penting dalam kultur jaringan untuk mendapat kalus, pucuk, maupun planlet (Trigiano \& Gray, 2005; Hartman et al., 2000). Kelompok zpt auksin sintetik seperti NAA, 2,4D dan sitokinin berupa benzil adenin, kinetin, dan thidiazuron merupan beberapa zpt yang sering digunakan dalam kultur in vitro. Penelitian ini bertujuan untuk mengkaji respon fisiologi daun kecubung terhadap beberapa macam zat pengatur tumbuh di dalam medium Murashige dan Skoog (MS) sehingga diperoleh kalus yang menjadi jaringan penghasil metabolit sekunder.

\section{METODE PENELITIAN}

Bahan tanaman yang digunakan adalah daun tumbuhan induk pada urutan ke 3 dari pucuk tumbuhan induk yang ditumbuhkan di dalam rumah kaca dan telah berbunga. Daun yang telah diisolasi kemudian dicuci dengan air mengalir dan deterjen, dilanjutkan sterilisasi permukaan di dalam LAF menggunakan larutan Natrium hipoklorit $10 \%$ selama 5 menit, selanjutnya dibilas dengan akuades steril. Daun steril tersebut digunakan sebagai eksplan dengan ukuran $1 \times 1$ $\mathrm{cm}$ ditanam di dalam medium perlakuan yakni medium MS padat yang mengandung beberapa macam ZPT. Perlakuan ZPT dalam induksi kalus kecubung terdiri dari : Kinetin (Kin) tunggal $3 \times 10^{-}$ ${ }^{5} \mathrm{M}$, NAA tunggal $10^{-5} \mathrm{M}$, BA tunggal $6 \times 10^{-6} \mathrm{M}$, kombinasi Kin-NAA,serta kombinasi BA-NAA dengan konsentrasi yang telah disebutkan. Analisis deskriptif dilakukan setelah subkultur ke 3 dengan parameter berupa morfologi eksplan dan atau kalus dan tekstur kalus. Kultur kalus dinkubasi pada kondisi terang di bawah pencahayaan lampu 1000 lux pada suhu $25^{\circ} \mathrm{C}$.

\section{HASIL DAN PEMBAHASAN}

Induksi kalus merupakan tahap pertama yang dilakukan dalam penelitian ini untuk menghasilkan kalus yang remah. Kalus remah menjadi syarat penting sebagai bahan utama untuk beberapa pengujian atau bioassay. Kalus yang remah disusun oleh sel-sel parenkim yang berdinding tipis, terorganisir saling lepas, berwarna kekuningan (Gambar 16A). Kalus demikian umumnya dikenal dengan kalus proliferatif dan mengandung metabolit sekunder (Veerpote \& Memmelink, 2002; Chawla, 2002).

Daun dipilih sebagai eksplan dalam pembentukan kalus, karena selain sebagai penghasil senyawa alkaloid kelompok tropan (Dewick, 2002), daun kecubung memiliki morfologi yang tipis dengan trikoma pada permukaan adaksialnya. Karakter daun tersebut memudahkan kontak dengan permukaan medium kultur yang padat, sehingga kalus dapat terbentuk dengan cepat. Hal ini mendukung penyediaan bahan utama pada pengujian selanjutnya. Respon daun kecubung sebagai eksplan yang ditumbuhkan pada medium Murashige\&Skoog (MS) dengan penambahan berbagai macam zat pengatur tumbuh disajikan dalam Tabel 1. Daun yang ditumbuhkan pada medium MS dengan beberapa komposisi zat 
pengatur tumbuh menunjukkan respon yang berlainan. Kalus yang remah dihasilkan dari medium MS dengan penambahan Kinetin $3 \times 10^{-5}$ $\mathrm{M}$ dan NAA $10^{-5} \mathrm{M}$. Kombinasi zat tumbuh Kinetin dan NAA tersebut sesuai untuk mendukung proses dediferensiasi daun kecubung secara in vitro. Hal ini menunjukkan bahwa kombinasi Kin dan NAA merupakan zpt yang tepat bagi kalogenesis daun kecubung. Kebutuhan jenis dan konsentrasi zpt sngat tergantung oleh genetik tumbuhan. Daun dari spesies lain dalam satu famili Solanaceae diduga memerlukan zpt yang berbeda jenis dan konsentrasi. Penggunaan kedua zat pengatur tumbuh tersebut dilakukan berdasarkan pada induksi kalus $D$. stramonium secara in vitro yang bertujuan untuk produksi alkaloid (Iranbakhsh et al., 2007).

Tabel 1. Respon eksplan daun Datura metel L. pada berbagai komposisi zat pengatur tumbuh dalam medium MS

\begin{tabular}{|c|c|c|c|}
\hline Zat tumbuh (M) & Kalus & $\begin{array}{c}\text { Jaringan } \\
\text { meristemoid }\end{array}$ & Akar \\
\hline $0(\tan p a \mathrm{zpt})$ & - & - & +++ \\
\hline Kinetin $3 \times 10^{-5}$ & + & - & - \\
\hline NAA $10^{-5}$ & ++ & - & ++ \\
\hline Kin $3 \times 10^{-5}+$ NAA $10^{-5}$ & ++++ & - & - \\
\hline BA $6 \times 10^{-6}$ & ++ & +++ & - \\
\hline BA $6 \times 10^{-6}+\mathrm{NAA} 10^{-5}$ & +++ & + & - \\
\hline
\end{tabular}

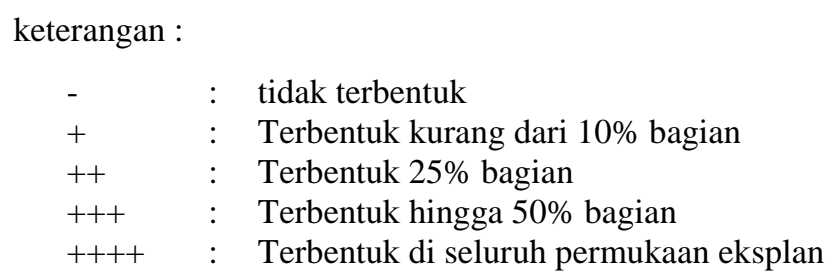

Kombinasi sitokinin lain, Benzil Adenin $6 \times 10^{-6} \mathrm{M}$ dengan NAA $10^{-5} \mathrm{M}$ menghasilkan kalus kompak berwarna hijau dengan jaringan meristemoid di sebagian permukaan. Jaringan meristemoid ini berwarna hijau yang mengindikasikan kandungan klorofil. Pembentukan klorofil ini memerlukan peran sitokinin, karena sitokinin merupakan kelompok hormon yang memiliki peran fisiologi dalam pembelahan sel termasuk kariokinesis dan sitokinesis (Davies, et al., 1987; Fosket, 1994). Pembelahan kloroplas sebagai organel dalam sitoplasma ikut dipengaruhi oleh sitokinin. Karakter kalus kompak yang demikian sangat mendukung untuk mikropropagasi yang menghasilkan planlet, maupun untuk pembentukan kultur pucuk. Kalus kompak semacam itu memiliki susunan jaringan yang rapat dan banyak mengandung air (Manuhara, 2001). Komposisi MS yang hanya mengandung Benzil Adenin (BA) tanpa NAA menghasilkan respon morfologi kalus yang berbeda dengan komposisi Kin-NAA maupun BA-NAA. Kalus kompak berwarna hijau dengan jaringan meristemoid yang mendominasi di permukaannya dihasilkan dari penggunaan BA $6 \times 10^{-6} \mathrm{M}$, merupakan kalus yang mengandung jaringan meristemoid yang selanjutnya berkembang membentuk tunas dan planlet (Gambar 1B). Benzil Adenin berperan dalam mengaktifkan gen-gen yang ada di dalam daun untuk membentuk tunas. Sadik et al. (2006) dan (Victor et al., 1999), menyatakan bahwa BA berperan menstimulasi pembelahan sel dan diferensiasi. Benzil Adenin merupakan sitokinin sintetik turunan adenin yang sangat aktif dalam mendorong pertumbuhan kalus tembakau. Bentuk isomer 1-bensil adenine mempunyai aktivitas kimia yang rendah, sehingga untuk dapat aktif harus diubah menjadi 6-bensil adenine. Sitokinin BA berperan penting dalam menginduksi respon 
fisiologi seperti regulasi pembelahan sel, diferensiasi jaringan dan organ serta biosintesis klorofil.

Respon perkembangan daun dari tiap spesies tanaman di dalam medium kultur berbeda satu sama lain. Pembentukan kalus dari daun tanaman rosela memerlukan zat tumbuh dengan kombinasi NAA $2 \mathrm{mg} / \mathrm{L}$ dan BA $3-5 \mathrm{mg} / \mathrm{L}$ di dalam medium MS. Kalus yang remah diperoleh baik dari daun maupun kelopak bunga tanaman tersebut, serta mampu menghasilkan asam askorbat (Nurchayati\&Rahmah, 2010) dan karotenoid (Noviati et al., 2014). Yuan et al. (2004), melaporkan bahwa kalus Alternanthera philoxeroides tumbuh optimal pada medium $1 / 2 \mathrm{MS}$, yang mengandung $\mathrm{BA} 3 \mathrm{mg} / \mathrm{L}$ dan NAA $0.2 \mathrm{mg} / \mathrm{L}$.

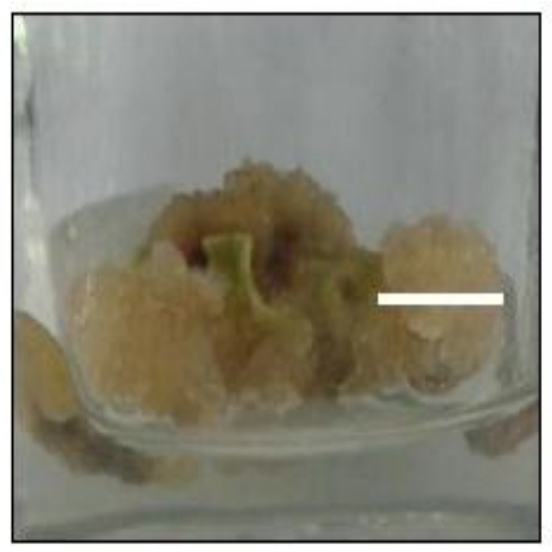

A

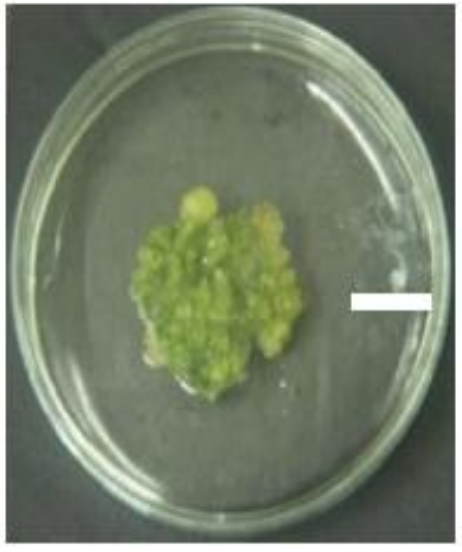

B

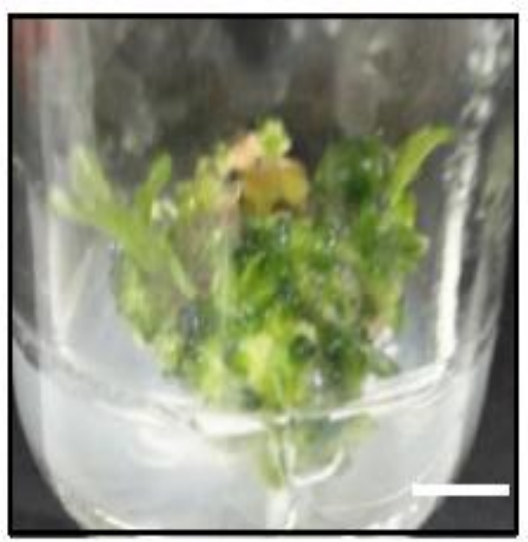

C

Gambar 1. Kalus dari medium MS dengan penambahan zpt A. Kinetin dan NAA; B. BA dan NAA; C. BA tunggal Skala: $1 \mathrm{~cm}$

Penambahan satu macam zat tumbuh, baik Kinetin tunggal maupun NAA tunggal, kurang mendukung pembentukan kalus kecubung. Hal ini ditandai eksplan hanya membentang dan menggulung pada 10 hari pertama, diikuti pembentukan kalus pada tepi-tepi irisan daun. Hingga akhir subkultur ke-3 (42 HST) sisa eksplan masih mendominasi. Pemberian BA tunggal maupun dikombinasi dengan NAA menghasilkan tipe kalus yang kompak dan banyak mengandung meristemoid. Menurut Sadik et al., 2006; Zhang et al., 2005, komposisi Kin-NAA merupakan kombinasi ZPT untuk memperoleh kultur kalus yang bertekstur remah, yang dapat digunakan dalam produksi metabolit sekunder, maupun untuk mendapatkan kultur suspensi sel. Kalus suspensi sel sangat tinggi potensinya sebagai sarana produksi metabolit sekunder. Kalus yang remah sangat tepat digunakan untuk mempelajari respon sel tumbuhan terhadap berbagai cekaman, antara lain cekaman kekeringan, salinitas dan cekaman logam berat secara in vitro (Chawla, 2002; Endress, 1994).

Kalus kompak yang dipenuhi meristemoid sangat memudahkan tahap organogenesis membentuk tunas adventif atau kultur pucuk. Kultur pucuk selanjutnya akan lebih mudah diinduksi membentuk akar tanpa perlakuan ZPT, sehingga dapat mendukung mikropropagasi tanaman. Kalus yang kompak umumnya dapat membentuk embrio (Trigiano \& Gray, 2005; Hartman, et al., 2000; Victor et al., 1999). Pembentukan embrio somatik juga sangat mendukung mikropropagasi pada beberapa biji tanaman yang sulit berkecambah atau biji yang non embrionik.

Induksi kalus secara in vitro umumnya memerlukan kombinasi aksin dan sitokinin. Penggunaan salah satu ZPT atau tidak adanya ZPT yang ditambahkan dalam medium hara tidak dapat menginduksi kalus secara optimal. Pada penelitian ini eksplan yang melengkung dan beberapa 
eksplan lainnya muncul, akar pada perlakuan tanpa adanya penambahan ZPT dalam medium dasar.

\section{KESIMPULAN}

Pemberian kombinasi Kinetin $3 \times 10^{-5} \mathrm{M}$ dan NAA $10^{-5} \mathrm{M}$ dalam media MS dapat menginduksi kalus Datura metel L. yang remah dan mendukung untuk sarana produksi metabolit sekunder. Penambahan BA tunggal $6 \times 10^{-6} \mathrm{M}$ dalam medium MS menginduksi kalus yang embrionik.

\section{DAFTAR PUSTAKA}

Ajungla, L., P.P. Patil, R.B. Barmukh, and T.D. Nikam. 2009. Influence of biotic and abiotic elicitors on accumulation of hyosciamin and scopolamine in root culture of Datura metel L.. Indian J. of Biotech. $8: 317-322$.

Alexander, J. Benford, D., Cockburn, A., Cravedi, JP., Dogliotti, E., Di Domenico, A., Fernandez-Cruz, M. L., Furst, P., FinkGremmels, J., Galli, C. L., Grandjean, P., Gzyl, J., Heinemeyer, G., Johansson, N., Mutti, A., Schlatter, J., van Leeuwen, R., Peteghem, C. V., and Verger, P. 2008. Tropane Alkaloids (from Datura sp.) as Undesirable Substances in Animal Feed. The European Food Safety Authority Journal 691: 1-55.

Bruce,N.C. 1999. Alkaloid. Cambridge,UK. www.wileyvch.de/books/pdf/v08a_alk.pdf

Chawla, H.S. 2002. Plant Biotechnology Laboratory Manual for Plant Biotechnology. Oxford dan IBH Publishing. New Delhi.

Dewick, P.M. 2002. Medicinal Natural Products A Biosynthetic Approach. John wiley \& sons. Ltd.

Endress, R. 1994. Plant Cell Biotechnology. Springer-Verlag Berlin, Heidelberg.

\footnotetext{
Facchini, P.J. 2001. ALKALOID BIOSYNTHESIS IN PLANTS: Biochemistry, Cell Biology,Molecular Regulation, and Metabolic Engineering Applications. Annu. Rev. Plant Physiol. Plant Mol. Biol. 52:29-66.
}

Nurchayati, Y. dan F.A. Rahmah. 2010. Kandungan asam askorbat pada Kultur Kalus Rosela (Hibiscus sabdariffa L.) dengan variasi Konsentrasi Sukrosa dalam Media MS. Majalah Obat Tradisional, 15(2), $71-74$.

Rahayu, S., R. R. Esyanti dan A.H. Siregar. 2006. Pengaruh Elisitasi dengan Verticillium dahliae Kleb dan Rhizoctonia Solani Kuhn terhadap kandungan Gosipol dalam kalus Gossypium hirsutum L. pada beberapa tingkat Subkultur. Biosfera 23 (1): 9-14.

Sadik, K., P. R. Rubaihayo, M. J. S. Magambo, and M. Pillay. 2006. Generation of cell suspensions of East African highland bananas through scalps. African $J$. of Biotechnology 6 (11) : 1352-1357.

Trigiano, R. N. and Gray, D. J. 2005. Plant Development and Biotechnology. CRC Press, Boca Raton.

Veerporte, R. and J. Memmelink 2002. Engineering secondary metabolite production in plants. Current Opinion in Biotechnology. 13: 181-187.

Victor, J.M.R., S.J. Murch, S. Krishna Raj, and P.K. Saxena. 1999. Somatic Embryogenesis and Organogenesis in Peanut: The Role of Thidiazuron and N6-Benzylaminopurine in The Induction of Plant Morphogenesis. Plant Growth Regulation 28: 9-15.

Zhang, L., G. Kai, B. Lu, H. Zhang, K. Tang, J. Jiang, and W. Chen. 2005. Metabolic Engineering of Tropane Alkaloid Biosynthesis in Plants. J. Integrative Plant Biol. 47 (2):136-143. 